\title{
The Eastern Roman Empire under Justinian
}

\author{
Prof. Univ. Ph. D. Marius Ţepelea \\ University of Oradea, Romania
}

\begin{abstract}
The Roman Empire that Justinian inherited no longer stretched over the whole Mediterranean region. It has been reduced to its eastern Greek-speaking half. In the Balkans, it controlled the area occupied now by Greece, Macedonia, Bulgaria, Albania and Serbia, wich together made up the prefecture of Illyricum. Its northern frontier was the Danube River, north of which were various Germanic, Hun and Slavic peoples who made constant incursions into imperial territory but thus far had made no permanent settlements. In Asia, the prefecture of the Orient comprised an area west of a frontier that ran roughly from the eastern tip of the Black Sea south to the Euphrates River, and from there across the desert of Jordan to the Gulf of Aqaba. In Africa, it controlled Egypt, and the southern part of present-day Libya. The former Roman Western Empire was occupied by barbarian kingdoms: the Vandal kingdom in North Africa, the Visigoth kingdom in Spain, the Frankish kingdom in France and the Ostrogoth kingdom in Italy.
\end{abstract}

Keywords: Eastern Roman Empire, Justinian, Constantinople, Roman army.

The greatest emperor of the Eastern Roman world was born in 482 in Tauresium, in the Roman province of Dardania, in a common peasant family that spoke Latin. His father was Petrus and his mother, Vigilantia. His birth name was Petrus Sabbatius; he took the name Justinian, much later, out of respect and love for his uncle, Emperor Justin I, who adopted him ${ }^{1}$ ). However, the scientists are not sure whether Justinian's family was of Roman-Tracian origin or of Roman-Illyrian. The real fact is that his mother, Vigilantia, was Justin's sister, the man who would become emperor in 518, following Emperor Anatasius I ${ }^{2}$ ).

The uncle made sure that his nephew would benefit the highest education possible by bringing him to Constantinople. Justinian read Roman Law and History, and even Theology, becoming an educated and faithful man. For a short period of time he served the Roman imperial guard as an excubitore. It seems that the nephew played an important role in his uncle's election, in 518, as the emperor of the most powerful and civilized state of the period. During Emperor Justin's 9-year reign, Justinian was his closest advisor. Because of his illness, just a few months before his death, the emperor brought his nephew to reign as an associate, in April $527^{3}$ ). On his death, in august 527, Justinian became the emperor of Eastern Roman Empire.

The empire he inherited from his uncle was much more different than that inherited by Arcadius from his father, Theodosius the Great. His predecessors had made everything to ensure a fortified Roman state, taking advantage of the weakness of the Sassanid Empire and of the decrease of power of the Barbarian tribes. Anastasius I had left in the empire's treasury a large amount of gold, 145 thousand kilograms; a fact that points to his excellent qualities as a leader, to the economic power of his coins, solidus and follies, and to proper economic management of his provinces in Orient. The Eastern Roman Empire no longer stretched over the whole Mediterranean region, but only in the Eastern part. In most Eastern Roman provinces people spoke Greek, although Latin was the official language. But in Egypt and Syria, Coptic and Aramaic were also spoken. Justinian inherited the Balkans, half of Illyricum, Asia Minor, Syria, Palestine and Egypt. The former Roman Western Empire was occupied

1 ) J. Moorhead, Justinian, Longman Publishing Group, London, 1994, p. 17.

2 ) M. Maas, Roman Questions, Byzantine Answers: Contours of the Age of Justinian, in vol. The Cambridge Companion to the Age of Justinian, ed. by M. Maas, Cambridge University Press, 2005, p. 5.

$\left.{ }^{3}\right)$ Procopius, Istoria secretă, VIII,3, col. Loeb Classical Library, no. 290, translated by H. B. Dewing, Harvard University Press, 1935, p. 92. 
by barbarian kingdoms: the Vandal kingdom in North Africa, the Visigoth kingdom in Spain, the Frankish kingdom in France and the Ostrogoth kingdom in Italy ${ }^{4}$ ).

Constantinople, which was founded by Constantine the Great, was the most important city of the empire and was then called Nova Roma. The historians believe it had probably 500 thousand inhabitants during Justinian period, but in 541 and 542, the plague killed $40 \%$ of its people. On the other hand, historian Procopius tells that 10 thousand people died on daily basis. This may be an exaggeration on his part, because the modern scientists estimate that only 5 thousand people were killed every day, thus the casualties in the capital reached the total number of 200 thousand $^{5}$ ).

The second and the third largest cities were Antioch and Alexandria, each having a population of aprox. 100 thousand inhabitants. The forth, was Thessaloniki, the capital of the prefecture of Illyricum. Recent studies show that there were aprox. 900 towns and citadels at the beginning of Justinian's reign, some having a little more over 3000-5000 people. Those in the Eastern part were well developed, most of them with churches, schools, public baths, libraries and other living facilities. They would also house the most powerful noblemen, while the most part of the people lived in the nearby villages, in prosperous communities working on large areas of arable land.

From the cultural point of view, Eastern Roman Empire was the most civilized state of the period. In the cities, most people spoke Greek, while in the villages, people spoke Coptic, Aramaic, Syrian, Armenian or another of the languages of the minorities ${ }^{6}$ ). The Empire was proud of its ancient Greek legacy, wrapped up in Christian clothes. The city people were familiar with the elements of the Christian theology and they gladly took part in Christological disputes. Each citadel and town had their own bishops, whose number was more than 1000 in Justinian's period. The bishop that lived in a capital of a province was an archbishop or metropolitan bishop and had several other bishops in his jurisdiction.

The bishops had the most influential power within the city, sometimes even greater than the imperial authorities. The metropolitan system was part of the patriarchal system. The most powerful and influent persons were considered to be the patriarchs of Constantinople, Alexandria, Antioch and Jerusalem. There was a brotherhood relationship among those four seats and the ancient one of Rome. But there were also exceptions: the tensions aroused during the ecumenical synods. Rome was under the control of the Ostrogoth kings of Italy who had Arian or semi-Arian creeds. The jurisdiction of popes stretched out to Illyricum and Northern Balkans which led to conflicts with the Patriarchy of Constantinople ${ }^{7}$ ).

This was the state that Justinian had to rule by himself; he had ruled before, during the last years of his uncle's reign, but behind closed door. In the most powerful state in the ancient times the ruling power had to be absolute, following the pattern of Oriental aristocracies. The Emperor ruled from the Imperial Palace, located in the South-east part of the capital. The Great Palace, called as Mega Palation by the emperor's subjects, spread over 149 acres (60 ha). It was an entire complex that comprised several buildings, like churches, audience halls and even an imperial stable. Close to the palace was the Great Racecourse, with a capacity of 80 thousand seats, and linked to the former by a tunnel which allowed the emperor to get directly to his imperial lodge (box). The centre of this complex was the Bronze House, a small palace that probably took its name after its bronze roof or doors. The Imperial Palace was also close to Saint Sophia Church were the Patriarch of Constantinople performed the Mass ${ }^{8}$ ).

\footnotetext{
$\left.{ }^{4}\right)$ J. A. Evans, The Emperor Justinian and the Byzantine Empire, Greenwood Press, Westport, Connecticut, 2005 , p. 9.

5 ) B. Croke, Justinian's Constantinople, in vol. The Cambridge Companion to the Age of Justinian, p. 61.

6 ) A. Dihle, Greek and Latin Literature of the Roman Empire: from Augustus to Justinian, Routledge, New York, 1994, p. 434.

7 ) A. Knecht, Die Religions-Politik Kaiser Justinians I: Eine kirchengeschichtliche Studie, Adamant Media Corporation, Boston, 2005, p. 63.

8 ) A. G. Paspates, The Great Palace of Constantinople, translated by W. Metcalfe, Kessinger Publishing, Whitefish, Montana, 2004, p. 27.
} 
During Justinian period, the imperial institution and the entire administrative system was inherited from the Romans, not yet changed into Greek and Oriental clothes. The people believed the emperor to be a descendant and heir of ancient Roman emperors; therefore greatly regarded by the Senate and the ordinary men who viewed themselves as Romans. When a new emperor was elected, the people gathered in the great square of the Racecourse, cheering and wishing him many victories in wars. After the election, he would be anointed emperor by the Patriarch of Constantinople, during a special coronation Mass, thus becoming also God's anointed.

In time, the imperial institution got an extremely complicated and sophisticated ritual; the king's presence in public was greatly exploited by the courtiers who maximized its ceremonial aspect. Justinian was the first emperor to ask for a complete bow to those coming to see him. Even the members of the Senate had to bow and kiss his feet ${ }^{9}$ ). He wore only fine and expensive clothes, thus a large amount of the empire's money went into the pockets of silk merchants. During hid reign, two monks managed to bring silk worm eggs from China, and they founded the bases of a local silk industry within the Eastern Roman Empire.

On their coronation, certain predecessors of Justinian would rather be crowned in the imperial lodge (box) on the Racecourse, while others, in various churches in Constantinople. Anastasius was the first emperor to bring into his coronation ceremony a pledge of loyalty, having religious references. Three months before his uncle's death, Justinian was made co-emperor and was crowned by the Patriarch of Constantinople, within a small religious ceremony. The coronation Mass was performed by the Patriarch of the imperial citadel, the emperors being anointed with holy myrrh, thus becoming also God's anointed.

Although the Roman emperors were autocrats, they were assisted by a consistorium, a council of imperial advisors that took its name after the hall where it had its first meeting. During Justinian's reign it had five state ministers, all members of the central imperial administration, and a few highly respected senators. The praetorian prefect and the prefect of Constantinople, two very important statesmen, were not members of this council, but they had the right to be invited to take part in its meetings. Besides the Consistorium, there was also a Senate of the imperial capital, following the model of the ancient Senate of Rome, founded by Emperor Constantius II ${ }^{10}$ ). But the Senate of Constantinople did not have much legislative power. Even if it had the right to make legislative proposals and to promulgate laws, this could be possible only with the emperor's agreement that also had the power of veto. Its members were chosen from the elite Roman society, and they were called illustres, spectabiles and clarissimi, but only the illustres had the right to speak in Senate.

Magister officiorum was the most important minister of the Consistorium. It was an administrative position created by Emperor Diocletian and enlarged by Constantine I. This minister was responsible for Scholae Palatinae, whose members would become imperial guards under Justinian. He also accounted for excubitores, as well as agents in rebus, i.e. imperial agencies, spies and couriers. Although he did not have military responsibilities, he was also in charge of the imperial arsenals and the armourers of the imperial army. In Justinian period, this minister had to represent the state in relationship with other foreign powers. The quaestori, tribuni, magisteri were also important statesmen, but the most important and most powerful was the great chamberlain, the praepositus sacri cubiculi, who controlled the access to the emperor and supervised the Great Palace. By an old tradition, the great chamberlain was eunuch, even if the Eastern Roman laws forbade castration. A legal artifice allowed that the eunuchs could be chosen from outside the borders of the empire ${ }^{11}$ ).

Diocletian managed to make an administrative reform between the years 284 and 305. His political, administrative, economic and military reforms prolonged the life of the Roman Empire with at least 150 years. The administrative system used in the Roman Orient was the same as 200 years before Justinian, in Diocletian's period. There were many small provinces, unequally divided, which were governed by a praeses (i.e. governor). A large number of governors would buy their positions, a custom that Justinian tried to dismiss, but unsuccessfully. Their responsibilities included

\footnotetext{
${ }^{9}$ ) J. A. Evans, op. cit., p. 60.

10 ) Mischa Meier, Das andere Zeitalter Justinians, Vandenhoeck \& Ruprecht, Göttingen, 2004, p. 118.

11 ) W. G. Holmes, The Age of Justinian and Theodora: a History of the Sixth Century A.D., vol. 1, Adamant Media Corporation, Boston, 2003, p. 168.
} 
administrative affairs, but also tax and fee collection, and to deliver justice. Even if they had under their command military troops, the garrisons and the small army divisions were commanded by a dux. Because of this, the latter had a greater power than the former. Several provinces formed a diocese, and several dioceses, a prefecture.

The prefecture of Illyricum had two dioceses, and that of Orient, five. Each diocese was governed by a vicarius. In time, their importance was not that great, Justinian was thinking of changing the administrative system of the dioceses, even from the very first years of his reign ${ }^{12}$ ). The praetorian prefects were the most influential men in the empire, but among those, the prefect of the prefecture of Orient, having his headquarters in Constantinople. He was believed to have the greatest power, because of his rank, even if that was not officially clearly expressed. By the nature of his office, this praetorian prefect would decide the taxes to be paid by the rural regions, supplied food for the army, made sure Constantinople had enough grains for the whole year and sent imperial requests and information to the imperial governors. Although he had the title of praetorian prefect, the man that used to command the Imperial Praetorian Guard in the former Roman Empire, he had no military responsibility. Constantine the Great dissolved the classic Praetorian Guard, and the office of praetorian prefect became a civil one. The jurisdiction of such a prefect did not reach the imperial capital; it had its own prefect with very specific responsibilities.

After the separation of the Western Roman Empire, the Eastern Roman Empire followed its own military path. The old Roman army, the one that had conquered the entire world by her force and good organization, with legions and cohorts made of only brave Roman, did not exit anymore. The cohorts had been replaced by larger army units, the numerus, having between 200 and 400 men, which were led by a military tribune. The army of the Eastern Roman Empire was basically formed, at the beginning of Justinian's reign, by soldiers recruited from ordinary Romans. It should be mentioned that the population of the state was of almost 34 million people. The recruited soldiers were called statiotai, and formed the basis of the armies of comitatenses, the elite army of the imperial troops. Justinian had inherited from his uncle a number of five comitatenses: two stationed in the capital, one, in Illyricum, one, in Thracia and one, in Antioch ${ }^{13}$ ).

Besides the stratiotai and comitatense, there were also limitanei, recruited from the people living on the outskirts of the empire. They had the responsibility of protecting the limes, and were deployed in the forts close to the borders of the Roman state. They were not as well trained or equipped as the comitatenses. Many of the forts they protected were vulnerable in cases of attacks, mainly because of the lack of military equipment. Besides those, the Romans also kept the foederati, troops initially made of barbarians that were considered allies. In Justinian era, they were almost as well organized and equipped as the stratiotai. They were both paid from the imperial funds. As opposed to the former Roman Empire, the Eastern Roman Empire would recruit foederati from the barbarians with whom it had signed alliances. Those treaties made the barbarian states send thousands of soldiers to fight for the Roman emperor. To make them adapt easier to the Roman military life, they would be put under the command of their barbarian leaders, men that were well paid and received large territories on their retirement ${ }^{14}$ ).

In addition to all these categories of soldiers, there was one more: the retired soldiers that were once more employed by the active officers. They were the bucellarii, recruited and paid by the commanders of the Roman emperor. Such an example is the great commander Belisarius. At first he was a simple bucellarius under the direct command of Justinian, and only afterwards did he escalate into military hierarchy and became famous and wealthy. In his period of fame, Belisarius had afforded to hire over 7000 bucellarii and paid for from his own money ${ }^{15}$ ). These bucellarii should not be

\footnotetext{
12 ) J. F. Haldon, Economy and Administration: How did the Empire work?, in vol. The Cambridge Companion to the Age of Justinian, p. 43.

13 ) W, Treadgold, Byzantium and its Army. 284-1081, Stanford University Press, Stanford, California, 1998, p. 98.

14 ) J. Haldon, Warfare, State and Society in the Byzantine World. 565-1204, Routledge, New York, 1999, p. 108.

15 ) J. Lessard, The Hero of Byzantium, iUniverse Inc., Bloomington, Indiana, 2005, p. 16.
} 
confused with the mercenaries who would appear much later in the Eastern Roman Empire and who had an important role in the victorious wars led but the Roman.

The most lethal Roman army troops were formed by mounted archers, equipped with a bow, a large amount of arrows and also a sword. They wore a light armor which allowed them to move easy and have a precise target. They were always accompanied by the heavy cavalry with its cataphractarii. These soldiers had a long lance, but also a sword and a bow with arrows. The cataphractarii wore a heavy armor and would break entire formations of the enemy's army with their devastating charge. The mounted archers were so well trained that they were able to shoot their arrow while horse ridding. At the beginning of the $6^{\text {th }}$ c., the Eastern Roman army was at its best, and Justinian took advantage of it by his numerous conquests ${ }^{16}$ ).

At the Southern border, the Romans had a century-old enemy, and probably the fiercest, the Persian Empire. The Arabic tribes were strong allies of the Eastern provinces, many sheiks being generously rewarded by Justinian for their services to the empire. Although the Persians were death rivals, Justinian did not start a final war with them, postponing an inevitable conflict. The great Roman army conquered a large part of Italy, Sicily and Northern Africa, making the Eastern Roman Empire the most powerful state of the period.

The Eastern Roman Empire had three strong support pillars: an efficient administration, an almost invincible army and the Christian Church. Christianity took huge steps since the Edict issued by Constantine and Licinius I, in 313. The former set the basis for restricting Paganism, a path followed by all his descendants, except Emperor Julian. Theodosius I made Christian religion the official religion of the Roman Empire, giving the final blow to Paganism by the edicts he issued and the financial constraints. The Church started to grow in the 4th c., becoming powerful and rich. She managed to pass over the turmoil triggered by the Arian controversy in the 4th c., and over the first break caused by the Nestorianism and Monophysitism, in the $5^{\text {th }} \mathrm{c}$.

At the beginning of the $6^{\text {th }}$ c., the Church of the Eastern Roman Empire, improper known as the Eastern Church, was the centre of the empire's spiritual life. The Patriarch of Constantinople was the second in rank, after the Bishop of Rome, and followed by the patriarchs of Alexandria, Antioch and Jerusalem. It was also a time period when the number of priests grew, especially that of inferior clerics due to the advantages of belonging to the Church. The Eastern Church became rich, receiving numerous donations from emperors and wealthy men. Saint Sophia Church had more priests than any other church in the Eastern Roman Empire. Justinian had to issue a law (535 AD) to establish the number of the clerics of Saint Sophia Church at a maximum of 525 priests, which points to the amount of religious servants of this great and unique cathedral. At the beginning of the $6^{\text {th }} \mathrm{c}$., there were cases of bishops that earned more money than governors of provinces, pointing to the power and influence of ranks in the empire ${ }^{17}$ ). The priests and the deacons, as well as the members of the inferior clergy, received a subsidy from the Roman state, according to each one's rank within the church.

There were several thousand monasteries in the Eastern Roman Empire at the beginning of the $6^{\text {th }} \mathrm{c}$. They owned important properties and received generous donations from Christians. The Church possessed more than the $6^{\text {th }}$ part of the territory of the Roman state, as well as the greatest part of the money on the market. By her power, influence and spiritual purpose, the Church was always ranked first in the people's everyday life. Throughout the year, there were various Christian holy days when people did not work and the emperors took great fast in participating, being examples for the common men. Following the tradition started by Basil the Great in Caesarea in Cappodacia, the Church had hospitals, homes for elderly people and orphanages. The bishops had the real power, a power even greater than that of the governors.

Apart from the government, administration, army and Church, Justinian was the emperor of his subjects, the common people. But who were those? Were they still Romans? Had they already adopted Greek customs and traditions? The Western Roman Empire had seized to exist four decades before. The Eastern Roman Empire was proud of its Roman legacy, and its citizens considered

\footnotetext{
16 ) J. Haldon, Byzantium at War, Osprey Publishing, Colchester, Essex, 2002, p. 48.

17 ) H. Chadwick, The Church in Ancient Society. From Galilee to Gregory the Great, Oxford University Press, Oxford, 2001, p. 613.
} 
themselves as Romans. Its capital was Constantinople and had a multicultural society where the most important aspects were social status, religion, culture and, only lastly, ethnicity ${ }^{18}$ ). The empire inherited by Justinian followed Roman laws, but adapted them to its own specificity, so it made a clear distinction between potentes, those belonging to the social class of the old aristocracy, and the humiliores, common people, the plebeians, as they were used to be called in the Western Roman world. The elite of the Roman society had the legislative, executive, economic and military power, so the potentes were protected by the law, which allowed them privileges and financial facilities.

The senators were the most privileged aristocrats. The Senate of the Eastern Roman Empire was in Constantinople, and it had been founded by Constantius II. The senators believed they were heirs of the Roman traditions of the ancient Senate, the venerable Senate of ancient Rome. The senators of Constantinople had different ranks; their number increased rapidly, and they became more than those of the senate of Rome. The ranks within the Senate were: illustres, spectabiles and clarissimi. At the beginning of Justinian's reign, only the illustres had the right to speak in the Senate. Although the Nika riots $(532 \mathrm{AD})$ of common people against Justinian were not started by the senators, after the revolt broke, they were fueled by certain spectabiles and clarissimi, in the belief of it being successful $\left.{ }^{19}\right)$.

The senators were the elite social class the emperor need, but the majority of the population was formed by humiliores. It has to be stated that not all of them were simple men; there were also merchants, modest local tradesmen, soldiers, small landowners, farmers, modest land workers, peasants, free people and slaves. The agriculture of the Western Roman Empire was dominated by vast estates where the labor force was: the migrant workers, the workers that were tied to it and the slaves. The free peasants that worked on the land of great estates in the Western Roman world were satisfied with their livelihood; they earned more than if they had their own land. The Eastern Roman Empire also had great estates, and they were also worked by simple peasants that lived better than in the Western Roman world due to the fact that they also had their own properties to work on. The laws of the Eastern Empire stated that the sons should have the same field of work as their fathers; especially for certain crafts and trades, thus social mobility and change of social status were often prohibited by law. But, in spite of all these, there could be seen an interesting social mobility. Justinian's uncle, Justin I, was a simple peasant that became emperor, by escalating the steps of the military hierarchy. Empress Theodora, Justinian's wife, was an actress that managed to become the most influent woman in the Eastern Roman Empire.

An overview could not be complete without mentioning the neighbors, allies and enemies of the Eastern Romans. After its fall, the former Roman Western Empire was occupied by barbarian kingdoms. North Africa became the Vandal kingdom, who had settled down there a century before Emperor Justinian. The Vandals destroyed the flourishing Roman provinces by confiscating the estates of the great African landowners. The luxurious and prosperous life changed the Vandals' living that ceased being powerful warriors. They had conflicts with the Berbers that constantly attacked the provinces of the Vandal Kingdom in Africa ${ }^{20}$ ).

On the ruins of Italy, in the former Western Roman state, a new kingdom appeared: the Ostrogoth kingdom, led for 37 years (up to 526 AD) by Theoderic the Great. They had occupied almost one third of Italy's land, having interesting politics: non-acceptance of Romans in the Ostrogoth government. But, there were still many Roman landowners enjoying all their privileges, because not all land had been confiscated by the occupants. Theoderic accepted the existence of the Senate of Rome, the forum that chose its consul each year, although the Romans did not enjoy any form of political government in Italy. Theoderic did not encourage any form of relationships between the Goths and the Romans or mix marriages. His politics were fueled by the religious environment: the Goths were Arians or semi-Arians, while the Romans, Christians, sharing the same beliefs with the

\footnotetext{
18 ) J. A. Evans, op. cit., p. 62.

19 ) A. Louth, The Eastern Empire in the Sixth Century, în The New Cambridge Medieval History, Cambridge University Press, 2008, p. 98.

20 ) A. Schwarcz, The Settlement of the Vandals in North Africa, în vol. Vandals, Romans and Berbers: New Perspectives on Late Antique North Africa, ed. by A. H. Merrills, Ashgate Publishing, Burlington, Vermont, 2004, p. 50.
} 
Eastern Church. Even after the last of the emperors of Rome had been cast away, the Roman people in Italy considered themselves subjects of the emperor of Constantinople. But, Ansatasius's Monophysitism prevented a closer alliance. When Justin I became emperor, he reestablished the relationship between the Churches of Rome and Constantinople, and the Romans in Italy became open to work with him. But the last years of King Theoderic had been filled with suspicion and paranoia: he believed his people were plotting with the emperor of Constantinople to kill him ${ }^{21}$ ).

Justinian began his reign thinking of re-conquering the former Western Roman provinces, mainly those of Italy and North Africa. His wish fulfilled between 533 and 534, when General Belisarios destroyed the Vandal kingdom in North Africa ${ }^{22}$ ). On the grounds of the former Vandal state, the emperor founded a new prefecture and gave Prefect Solomon, Belisarios's descendant, both, civiladministrative and military powers, (a most uncommon fact), due to the unusual situation of the province. Even before Belisarios left North Africa, the Berbers had started riots that continued during Solomon's administration. The capable prefect and general had fought the Berbers for eleven years, gaining many fights, until his death, in 544, during a campaign against the same enemies. Due to the incompetence of his successors in administration, the situation became worse, thus Justinian sent one of his greates generals in Africa, John Troglita, dux of Mesopotamia. He defeated the Vandals, reinstating the Roman authority over the prefecture. Archeological excavations on that territory revealed that the Eastern Roman era was a flourishing one, mainly because of commerce and prosperity ${ }^{23}$ ).

The Justinian troops also conquered the most part of the prefecture of Italy, destroying the Ostrogoth kingdom. Its capital was Ravenna, while the civil and military headquarters were in Narses during the emperor's reign. Justinian's crowning brought great hopes for the Italians, most of them remembering the glory of the former empire that had been destroyed by the Heruli tribes only 51 years before. Unfortunately for them, just a few years after Justinian's death, the Lombards invaded Italy, settling down mainly in its Northern part.

If Italy was part of the ambitious plan of the emperor to rebuild the greatness of a united empire, Spain was not included. There, there was the Visigoth kingdom from the $5^{\text {th }} \mathrm{c}$. Taking advantage of a dynastic conflict between the Visigoths, Justinian sent in an army to help Athanagild, in 552. The latter secretly became a Christian, giving up Arianism. The Roman troops stationed in Spain and managed to secure the Roman possession till $624^{24}$ ).

On the North of the Danube, two large migrating peoples started both, a conflict between themselves and a conflict with Justinian: the Bulgar people and the Slavic people. The former belonged to the migrant family of the tribes in Ural-Altai, coming from Asia and settling down near Volga. Towards the end of Justinian's reign, the Roman troops in the Eastern territories met new migrant tribes: the Avars who had left from the region of Mongolia and China under the pressure of the Turks. The Avars were the ones that drove the Bulgars and the Slavs away. The Roman emperor managed to keep peace with the Avars by offering them an annual amount of money and by trying to diplomatically focus their attention to enemies outside the borders of the Roman Empire.

When analyzing all frontiers and allies of the Justinian Roman Empire, there is an obvious Achilles heel for Constantinople: the Balkans. The historian Procopius of Caesarea tells that the Huns, the Bulgars and the Slavs constantly raided Illyricum and Thracia every year of Justinian era. In 540, a small Bulgar army cross the Danube and reached as far as Thessaloniki and even threatened the imperial capital by holding hostage 100000 Romans. Although the Slavs and the Bulgars had permanently harassed the imperial troops, they did not settle down in large masses on the South of the Danube. At the end of this period, the natural border offered by the Danube was still intact ${ }^{25}$ ).

\footnotetext{
21 ) T. S. Burns, A History of the Ostrogoths, Indiana University Press, 1991, p. 68.

22 ) I. Hughes, Belisarius: The Last Roman General, Westholme Publishing, Yardley, Pennsylvania, 2009, p. 152.

23 ) The Prosopography of the Later Roman Empire, ed. by J. Martindale, vol. III, Cambridge University Press, p. 644.

24 ) E. A. Thomson, The Goths in Spain, Oxford University Press, Oxford, 2000, p. 321.

25 ) Procopius, Istoria secretă, XXI,26, p. 253.
} 
The Persian Empire, the neighbor on Western border, was the Roman's Empire strongest enemy, an old and constant enemy. Together with his empire, Justinian also inherited an uncomfortable and pending war with Persia. Belisarios, one of the greatest Roman generals, had two important victories against the Persians, in 530, but a year later he was defeated on the riverbank of Euphrates. At a certain point, both empires realized that a peace treaty was the best solution. Thus, in 533, they signed a peace treaty that lasted seven years, until Emperor Chosroes I (i.e. Anushirvan) invaded Eastern Roman provinces (540 AD) and destroyed Antioch. A new peace treaty was signed only in 561, although the war started by Chosroes had ended in $545^{26}$ ).

The rivalry between the two empires spread over a large area, reaching up to the North of the Black Sea, in the region of Lazica, today's Georgia. In 522, Georgian king Tzath baptized in Constantinople, triggering a negative reaction from the Persians. But in 561, after many conflicts, Persia gave Lazica to the Romans. Justinian did not neglect the Eastern borders of the empire, so after the peace signing with the neighboring empire, he began his attempts to re-conquer the Western territories. The great plaque of 541 was the only obstacles in achieving his plans ${ }^{27}$ ).

There were millions of deaths which affected both, the state and the army. Towards the end of Justinian era, the Roman army barely had 150000 soldiers scattered on all battle fronts. The Empire had vast territories and it was fragile. All the conquests made after 527 were not balanced and strengthened by long term political, economic and military measures. Those should have been taken to ensure the integration of the new territories within the Eastern Roman Empire. When Justinian first became emperor nobody believed he could succeed in his plans: to rebuilt the former glory and prestige of the Roman Empire.

\section{AUTHOR'S BIOGRAPHY}

$\mathrm{Ph}$. D. in Theology, at University of Oradea, Romania, 2003.

Current job: Prof. univ. at University of Oradea, Romania.

Author of 12 books (in Romanian) and 60 articles.

Member of: The Ecclesiastical History Society and International Network for the Study of Late Antiquity.

\footnotetext{
${ }^{26}$ ) A. D. Lee, The Empire at War, in vol. The Cambridge Companion to the Age of Justinian, p. 131.

27 ) W. Rosen, Justinian's Flea: The First Great Plague and the End of the Roman Empire, Penguin, London, 2008, p. 199.
} 